\title{
CAMA
}

Centre for Applied Macroeconomic Analysis

\section{The Impact of Social Justice on Economic Performance}

\section{CAMA Working Paper 18/2017 March 2017}

\author{
Anil Savio Kavuri \\ Centre for Applied Macroeconomic Analysis, ANU
}

\section{Hongwei Shao}

School of Economics, Xiamen University

College of Business and Economics, ANU

\section{Abstract}

A large body of literature shows that institutions positively impacts economic performance. This study proposes that social justice which is an essential virtue of institutions also positively influences economic performance. We build the case that social justice affects capital, human capital and technology accumulation. This in turn positively drives economic performance. The hypothesis is empirically supported with a cross-sectional analysis of OECD countries and panel data analysis of EU countries. The results are robust under Instrument Variable (IV) analysis and numerous controls. The examination also determines that social justice contributes significantly to the traditional neoclassical model that relates output to the stock of human and physical capital. Consequently, the results imply that if a country such as Turkey is able to raise its rating to the level of Nordic countries (e.g. Norway), GDP per capita may increase from 10,000 USD to 56,000 USD. 


\section{Keywords}

JEL Classification

\section{Address for correspondence:}

(E) cama.admin@anu.edu.au

\section{ISSN 2206-0332}

The Centre for Applied Macroeconomic Analysis in the Crawford School of Public Policy has been established to build strong links between professional macroeconomists. It provides a forum for quality macroeconomic research and discussion of policy issues between academia, government and the private sector.

The Crawford School of Public Policy is the Australian National University's public policy school, serving and influencing Australia, Asia and the Pacific through advanced policy research, graduate and executive education, and policy impact. 


\title{
The Impact of Social Justice on Economic Performance
}

\author{
Anil Savio Kavuri and Hongwei Shao*
}

February 24, 2017

\begin{abstract}
A large body of literature shows that institutions positively impacts economic performance. This study proposes that social justice which is an essential virtue of institutions also positively influences economic performance. We build the case that social justice affects capital, human capital and technology accumulation. This in turn positively drives economic performance. The hypothesis is empirically supported with a cross-sectional analysis of OECD countries and panel data analysis of EU countries. The results are robust under Instrument Variable (IV) analysis and numerous controls. The examination also determines that social justice contributes significantly to the traditional neoclassical model that relate output to the stock of human and physical capital. Consequently, the results imply that if a country such as Turkey is able to raise its rating to the level of Nordic countries (e.g. Norway), GDP per capita may increase from 10,000 USD to 56,000 USD.
\end{abstract}

\section{Introduction}

This paper hypothesises that social justice is a 'fundamental cause' (Acemoglu, Johnson, and Robinson, 2005) of economic performance. Social justice positively impacts 'proximate causes', namely technology, labour and capital accumulation (North and Thomas, 1973 ) to enhance economic performance.

First, it is important to define social justice. Rawls (2009) states on the opening page of Theory of Justice, 'Justice is the first virtue of social institutions.' Fair equality of opportunity for all is consequently implied. According to Miller (1999) social justice determines resource allocation to individuals by institutions. Miller identifies three

\footnotetext{
* Anil Savio Kavuri: Centre for Applied Macroeconomic Analysis, Crawford School of Economics, Australia National University, Building 132, Lennox Crossing, Acton, Canberra, ACT 2601, Australia (telephone: +61 26125 0579; email: Anil.Kavuri@anu.edu.au). Hongwei Shao:College of Business and Economics, Australia National University, Canberra, ACT 2601, Australia and the School of Economics, Xiamen University, No. 422, Siming South Road, Xiamen, Fujian, 361005, China. We are particularly grateful to Warwick J. McKibbin. We also thank Matthew Stanhope, David Stern, Xin Liu and the anonymous referees for their informative comments. Hongwei Shao received financial support from China Scholarship Council/ Australian National University Joint Funding Program which is gratefully acknowledged. The authors declare that he has no relevant financial interests that relate to the research in this paper.
} 
key principles which connect to the notion of social justice. What we deserve, what we need and equality. On these fundamentals, one can judge a government. Consequently, most theorists would agree that social justice is a desirable standard that holds institutions accountable. Social justice is a concrete term embedded in culture. For instance, the United Nations General Assembly approved on 26 November 2007, starting in 2009, 20 February as the World Day of Social Justice. The United Nations highlight that social justice should enable all to bear fair fruits of economic growth. This covers political, economic and social justice. According to the United Nations, social justice involves equality of rights, opportunities and equity in living conditions. In defining concrete elements, the body goes on to emphasises distribution of income and assets, opportunities for work and remuneration, access to knowledge, health services with fair civic and political participation. In addition, the neglect of social justice will lead to a future repression and chaos. ${ }^{1}$

It is clear that institutions are fundamental to upholding social justice. The relevant institutions include health, education, labour laws taxation among others. Smith (1776) argued that the free market and also the justice system and rule of law as critical for economic growth. Since then early institutionalist (e.g.Veblen, 1899) and later new institutional economics (e.g. North and Thomas, 1973; Williamson, 1985) have offered theories linking institutions to growth. It is now widely accepted that institutions matter to economic performance (Acemoglu, Johnson, and Robinson, 2001; Rodrik, Subramanian, and Trebbi, 2004 Acemoglu et al., 2005; Acemoglu and Robinson, 2012). However, what is missing in this research is the analysis of whether principles that hold institutions accountable matter to technology, capital, labour and consequently to economic performance. This paper aims to contribute by evaluating these dynamics.

Empirically, the hypothesis is supported with a cross-sectional analysis of OECD countries and with panel data analysis for EU countries. The results are robust under Instrument Variables (IV) analysis, controls and various regression methods including Ordinary Least Squares (OLS), random effects and between estimates. This paper uses social justice indices which reflect evaluations by over 100 experts. Countries are rated 1 to 10 . The OLS regression illustrates that for OECD countries for only one point increase $^{2}$ in the weighted social justice index, GDP per capita would increase by 61 $\%$ when controlling for the endogeneity. This implies that if a country such as Turkey could increase social justice to the level of Norway, GDP per capita would increase from 10,000 USD to over 56,000 USD. Given that social justice has a positive effect on economic performance, it is clear that policy should be devised to improve social justice. The analysis may also provide guidance on the set of required policies. A multidimensional strategy that takes into account the lagging areas of social justice (i.e. poverty prevention, inclusive education system, labour market access, social cohesion, health and inter-generational justice) is desirable.

\footnotetext{
${ }^{1}$ For an overview of the inequality-economic development debate see Galor (2009a). As pointed out by Galor (2009a) the classical perspective emphasises that inequality benefits growth, whereas the modern day perspective predominately argues for the negative impact on development. Channels for the adverse impact of inequality on growth include political economy (Alesina and Rodrik, 1991; Alesina and Perotti (1996); Persson and Tabellini, 1994), credit market imperfections (Galor and Zeira, 1993) and fertility (Galor and Zang, 1997). Nonetheless, channels for the positive impact results from the accumulation of savings.

$210 \%$ increase.
} 
This paper attempts to avoid the methodological critiques of some institutional work. It is important to note that even the most important papers in the field including Acemoglu et al. (2001), Acemoglu, Johnson, and Robinson (2002) and Acemoglu et al. (2005) has faced criticisms. For instance, Albouy (2004), Albouy (2008) and Albouy (2012) is concerned with the conjectures and assumptions made in those papers. Consequently, we do not make conjectures on what social justice should be nor on the ratings of countries. The empirical work adopts an index which reflects assessments by more than 100 experts in the social justice field. Glaeser, La Porta, Lopez-de-Silanes, and Shleifer (2004) also raises a number of methodological problems highlighting that measures of institutions such as the risk of expropriation by the government do not characterise political institutions. As this paper adopts an independent social justice index, we hope not to succumb to this methodological problem.

Secondly, as only social justice is addressed, separating out the underlying causes is not be fraught with difficulty. Notice that Carlin, Schaffer, and Seabright (2010) argue that an inherent methodological problem lies with most empirical institutional work, in the use of proxies. The authors suggest that there are too many underlying causes such as capitalism, corruption etc. to correctly choose which one. Carlin et al. (2010) observe that separating out their effects is nearly impossible.

The rest of this paper is organised as follows. In the next section, the case for the impact of social justice on economic performance is formulated. Section 3 will discuss the empirical results. First, the OECD countries will be investigated, after which the EU results are presented. Section 4 examines the contribution of social justice to the traditional neoclassical model. Section 5 provides concluding remarks.

\section{The role of social justice in economic performance}

According to institutional literature, (North and Thomas, 1973 and Acemoglu et al., 2005) institutions are the fundamental cause of economic performance. We hypothesise that social justice is also a 'fundamental' cause. Social justice impacts technology, human capital and physical capital. While other factors play a role, the focus here is to determine the extent of social justice's impact on performance.

\section{Marginal product of social justice}

This paper proposes that the marginal product of social justice $\psi_{S J}^{\prime}$ on output can be estimated through econometric regression analysis.

$$
\frac{\partial Y(t)}{\partial S J(t)}=\psi_{S J}^{\prime}
$$

This is the hypothetical price of social justice, the shadow price. This marginal product provides the marginal benefit on the output of increasing social justice. In the empirical analysis, $Y(t)$ is $G D P$ per capita of a country, with $S J(t)$ measured by a social justice index. Nonetheless, the mechanism by which social justice acts on economic 
performance is through proximate causes ${ }^{3}$ of technology, human capital ${ }^{4}$ and physical capital. For our main investigations, we do not run regressions with proximate causes and fundamental causes together ${ }^{5}$. However, to validate the conjecture, we also regress social justice on the proximate causes. It is well-known that North and Thomas (1973) argue that:

'The factors we have listed (innovation, economies of scale, education, capital accumulation, etc.) are not causes of growth, they are growth'.

Now let us consider the impact of social justice on each proximate factor in turn.

\section{Labour}

$$
Y(t)=\psi(A(t), K(t), L(t)))
$$

where $Y(t)$ is output, $A(t)$ is technical change, $L(t)$ is labour. Labour can be further broken down into the following:

$$
Y(t)=\psi(A(t), K(t),[E(t) P(t) \lambda(t)]))
$$

where $E(t)$ is human capital consisting of education and health, $P(t)$ is population and $\lambda(t)$ is participation rate.

$$
\begin{aligned}
& \dot{E(t)}=f_{E}(S J(t), x(t)) \\
& \dot{\lambda(t)}=f_{\lambda}(S J(t), x(t))
\end{aligned}
$$

$x(t)$ is any other structural factors.

As can be seen, social justice is proposed to impact human capital accumulation through education, health and the workforce participation rate, which are all positively related to economic performance. Let's consider why? Adhering to Miller (1999)'s three notions of social justice, all individuals will necessarily have opportunities for good health and education. Social justice necessarily ensures educational opportunities. Clearly, individuals have opportunities to borrow to fund education. Economic research has shown that opportunities to borrow for education are positively related to economic output. Pioneering research by Galor and Zeira (1993) and Galor (2000) determined that people with low wealth with credit constraints implies underinvestment in human capital and consequently aggregate output will be lower. Low-income households are unable to afford education fees and hence leave education. Further, individuals with low wealth will be unable to make socially optimal investments. This leads to lower aggregate output. Galor, Moav, and Vollrath (2009b) shows that land concentration, effectively income inequality negatively impacts human capital building institutions which partly explains the disparity in income per capita across nations.

Now consider health. Necessarily, fair equality of opportunity provides access to

\footnotetext{
${ }^{3}$ Persson and Tabellini (1994) in their investigation into political institutions highlight that economic growth is largely determined by capital accumulation, human capital and production knowledge.

${ }^{4}$ The debate on the impact of education attainment on economic performance is well-known. See Temple (1999) and Benhabib and Spiegel (1994) for two contrasting views.

${ }^{5}$ However, in section 4 we regress social justice together with proximate causes to understand the contribution of social justice to the traditional neoclassical approach.
} 
adequate health for all. Good health, in turn, has been found to be positively related to output. Weil (2014) highlight that healthier individuals learn more in school and face higher incentives to accumulate human capital due to longer lives. Well (2007) uses microeconomic estimates to formulate a proximate effect of health on GDP per capita. Well (2007) determines that eradicating differences in health among countries would reduce the variance of log GDP per worker by $9.9 \%$. In essence, he finds a positive effect of health on GDP per capita.

Social justice seeks to ensure that no one is discriminated against and there is inclusion. It also enables participation in the workforce. To empirically estimate the impact of social justice on human capital accumulation, human capital per worker is used from the Penn World Table 8.1. (University of Californa and the Groningen Growth Development Centre, n.d.) As social justice emphasises inclusion of individuals, labour participation from the WDI database (World Bank, n.d.-a) is also used.

\section{Physical capital}

Social justice positively impacts physical capital accumulation. There are a number of reasons. First, social justice ensures that entrepreneurs are able to borrow and consequently are not credit constrained. Fundamentally, the outcome is the same as highlighted by Banerjee and Newman (1993). Their paper categorises three occupations: entrepreneurship, self-employed and paid employment. Poor people lack the wealth and are usually too credit constrained to become entrepreneurs. In their model, the best outcome is when the number of poor is low. Consequently, Parker (2009)'s policy recommendation is to relax borrowing constraints. Aghion, Banerjee, and Piketty (1999) shows that inequality may be a source of macroeconomic instability which leads to longer suboptimal growth periods. Their policy recommendation is also to reduce inequality of access to investment opportunities. Under the same lines of reasoning, our policy recommendation would improve social justice. If there is social justice, then borrowing constraints are naturally low.

There are other avenues how social justice impacts physical accumulation. Individuals with access to education or those who do not suffer significant discrimination will obtain higher wages. This will enable more saving and hence higher economic performance.

$$
\dot{K(t)}=f_{K}\left(S J(t), x_{K}(t)\right)
$$

$x_{K}(t)$ are structural factors such as interest rate.

To empirically investigate this conjecture this paper uses data for log physical capital per worker from Penn World Table 8.1. (University of Californa and the Groningen Growth Development Centre, n.d.)

\section{Technology}

Social justice ensures the existence of property rights which provide the necessary incentives for research and development. However, entrepreneurs will not be denied access to knowledge unduly. As highlighted by Doepke and Zilibotti (2014) ever since ground-breaking work by Schumpeter, there is a general understanding that entrepreneurs are the 'engines' of growth. The authors present an endogenous technical 
change model with entrepreneurs being central to innovations.

$$
\dot{A(t)}=f_{A}\left(S J(t), x_{A}(t)\right)
$$

$x_{A}(t)$ are other factors

As a proxy for technology, total factor productivity from the Penn World Table 8.1 ( (University of Californa and the Groningen Growth Development Centre, n.d.)) is used.

The empirical analysis and results are discussed in detail in the next section. Nonetheless, note that we regress GDP per capita on social justice. We do not regress GDP growth rate on social justice. GDP growth rate is unsuitable for the analysis for two reasons. For OECD countries with only one social justice indicator available, there is no rate of change for the index. Although for EU countries a panel data set is available, a regression of GDP growth rate on social justice will be biased due to the catch-up effect. In economic literature, the catch-up effect is well-known. Note that recent papers include J.-W. Lee (2016a) and J.-W. Lee (2016b) that highlight the effect for China.

\section{Empirical analysis}

\subsection{Data}

This paper utilises the social justice indices compiled by Bertelsmann Stiftung (n.d.). The sample consists of the 31 OECD and 28 EU countries. For the OCED sample, a cross-sectional analysis was undertaken as only one year of the social justice index is available. i.e. for 2011. For the EU sample, a panel data analysis was undertaken with measurements for three years of the social justice indexes $(2008,2011,2014)$ exploited. There are two social justice indices (weighted and unweighted) of which the emphasis is on inclusion rather than compensating for exclusion. The indices are multidimensional with six elements covered: poverty prevention, inclusive education system, labour market access, social cohesion, health and inter-generational labour. There are twenty-seven quantitative and eight qualitative indicators for each one of the six dimensions of social justice. According to experts Merkel and Giebler (2009) (Schraad-Tischler, 2011) poverty prevention, access to education, and labour market access have greater conceptual value, hence for the weighted index, are weighted heavier at 30\%, 20\%,20\% respectively. The other three dimensions are all weighted $10 \%$ each. The unweighted index is also adopted for regression analysis in this paper.

These indices have various advantages over proxies constructed in the institutional literature. Importantly, this paper does not make subjective claims to construct the proxy. As highlighted earlier, institutional literature has faced many criticisms of conjectures made in the investigations. Although the social justice indices include qualitative measures, they are based on evaluations from more than one hundred experts in the social justice field. The questionnaire allows for specific ranking with a scale of 1 being the lowest to 10 the highest. The quantitative indicators also provide assistance to the experts making the qualitative assessments. We do not make any conjectures on the characteristics of social justice nor the ranking of countries.

Two measures of economic performance are adopted; log GDP per capita obtained 
from the World Bank database (World Bank, n.d.-b) and log output per worker obtained from the Penn World Table 8.1 (University of Californa and the Groningen Growth Development Centre, n.d.). For EU countries log GDP per capita for years between 2007 to 2014 was obtained. For OECD countries only data for 2011 was required. Nonetheless, for OECD countries, we also investigated the impact of social justice on technology, physical and human capital. Data for log physical capital per worker, human capital per worker and total factor productivity are all taken from the Penn World Table 8.1. As social justice emphasises the inclusion of individuals, labour participation from the WDI database (World Bank, n.d.-a) is also regressed on the social justice index.

\subsubsection{OECD: OLS regressions}

This section shows empirically that social justice at a $1 \%$ significance level positively impacts economic performance.

Table 1 reports the ordinary least-squares (OLS) regressions on the weighted social justice and unweighted social justice index. The empirical specification for the crosssectional analysis is as follows:

$$
Y_{j i}=\alpha_{j k}^{a}+\beta_{j k} S J_{k i}+\varepsilon_{j k i}^{a}
$$

$j=\{1,2,3,4,5,6\}$.

$k=\{1,2\}$

$Y_{j i}$ represents $\log$ GDP per capita, log output per worker, log physical capital per worker, human capital per worker, total factor productivity and labour participation for county $i$ respectively.

$S J_{k i}$ representing the weighted and unweighted social justice index for country $i$.

$\alpha_{j k}^{a}$ and $\varepsilon_{j k i}^{a}$ is the intercept and the error term respectively. ${ }^{6}$

$\beta_{j k}$ is the effect of weighted and unweighted social justice indexes on log GDP per capita or the various proximate causes. ${ }^{7}$

Table 1 and Table 2 shows the results for the regressions on the weighted and the unweighted social justice indices respectively. ${ }^{8}$ Columns (1), (2), (3), (4), (5) and (6) are the regressions of log GDP per capita, log output per worker, log physical capital per worker, human capital per worker, total factor productivity and labour participation on the weighted and unweighted social justice indices. ${ }^{9}$.

There is a strong correlation between the impact of social justice (both weighted and unweighted) on GDP per capita. The coefficients imply that there is approximately $42 \%$ and $48 \%$ increase in GDP per capita for only one point increase in the weighted and unweighted social justice indices. The two regressions are significant at a $1 \%$ level with $R^{2}$ over $53 \%$ and $63 \%$. This suggests that over $50 \%$ of the variation in GDP

\footnotetext{
${ }^{6}$ Due to the large number of regressions, to simplify notation,we use $\alpha_{j k}$ and $\varepsilon_{j k i}$ throughout the paper for the constant and error term. We superscript them by letters of the alphabet to distinguish the equations. Notation which is self-explanatory is not explicitly defined.

${ }^{7}$ Note that there are 12 different lines. e.g. $\beta_{11}=0.4298, \beta_{21}=0.1398, \beta_{12}=0.4821$

${ }^{8}$ For all the tables in this paper, standard errors are in parentheses. $* * * p<0.01, * * p<0.5, * p<0.1$

${ }^{9}$ For the OECD countries, the social justice indices are only available for 2011 . Consequently we use data for 2011 for all the other variables
} 
per capita is explained by social justice. Figure 1 presents regression of log GDP per capita on the weighted social justice index. As can be seen, Turkey is at the bottom. The regression calculates GDP per capita for Turkey at $e^{7.4096+0.4298(4.2)}=10,004$ USD. If Turkey was able to increase social justice to the rating of Norway the regression suggests that GDP could increase to $e^{7.4096+0.4298(8.2)}=56,050$ USD. There are some interesting outliers. The Czech Republic scored very well in the social justice index relative to its economic performance. The country achieved the second highest rating out of all the countries for poverty prevention and did well in terms of health. The United States has a relatively low social justice index. As $17 \%$ of the population in the United States lives on less than $50 \%$ net median income, the country scored badly in poverty prevention.

Table 1 and 2 also report the impact of social justice on proximate causes (human capital, physical capital and technology). The results vary between strong significance and weak significance. There is a strong significance of social justice on log physical capital per worker. The regressions are significant at a $5 \%$ and $1 \%$ level. However, the results show relatively low significance for human Capital/Worker and Total Factor Productivity. This implies that the impact of social justice on human capital and technology is weak. Nonetheless, as can be seen in tables, social justice impacts labour participation.

In summary, the ordinary least squares show a strong correlation between social justice and GDP per capita. Furthermore, the analysis illustrated that social justice strongly impacts physical capital per worker and labour participation. It has a relatively weak effect on technology. 
Table 1: OLS Regressions: Weighted Social Justice Index

\begin{tabular}{lllllll}
\hline & $(1)$ & $(2)$ & $(3)$ & $(4)$ & $(5)$ & $(6)$ \\
& $\begin{array}{l}\text { Log GDP } \\
\text { /Capita }\end{array}$ & $\begin{array}{l}\text { Log Output } \\
\text { /Worker }\end{array}$ & $\begin{array}{l}\text { Log Physical Capital } \\
\text { /Worker }\end{array}$ & $\begin{array}{l}\text { Human Capital } \\
\text { /Worker }\end{array}$ & $\begin{array}{l}\text { Total Factor } \\
\text { Productivity }\end{array}$ & $\begin{array}{l}\text { Labour Participation } \\
\text { Rate }\end{array}$ \\
\hline Social Justice (Weighted) & $0.4298^{* * * *}$ & $0.1393^{* * *}$ & $0.1700^{* * *}$ & 0.0757 & 0.0348 & $4.7087^{* * * *}$ \\
& $(0.0743)$ & $(0.0443)$ & $(0.0635)$ & $(0.0461)$ & $(0.0237)$ & $(0.7719)$ \\
Constant & $7.4096^{* * *}$ & $10.1058^{* * *}$ & $11.1945^{* * *}$ & $2.5839^{* * *}$ & $0.5998^{* * * *}$ & $40.6180^{* * *}$ \\
& $(0.5018)$ & $(0.2993)$ & $(0.4291)$ & $(0.3116)$ & $(0.1601)$ & $(5.2120)$ \\
$R^{2}$ & 0.5356 & 0.2542 & 0.1979 & 0.0848 & 0.0691 & 0.5620 \\
Observations & 31 & 31 & 31 & 31 & 31 & 31 \\
\hline
\end{tabular}

\begin{tabular}{|c|c|c|c|c|c|c|}
\hline & $\begin{array}{l}(1) \\
\text { Log GDP } \\
\text { /Capita }\end{array}$ & $\begin{array}{l}\text { (2) } \\
\text { Log Output } \\
\text { /Worker }\end{array}$ & $\begin{array}{l}\text { (3) } \\
\text { Log Physical Capital } \\
\text { /Worker }\end{array}$ & $\begin{array}{l}\text { (4) } \\
\text { Human Capital } \\
\text { /Worker }\end{array}$ & $\begin{array}{l}(5) \\
\text { Total Factor } \\
\text { Productivity }\end{array}$ & $\begin{array}{l}(6) \\
\text { Labour Participation } \\
\text { Rate }\end{array}$ \\
\hline Social Justice (Unweighted) & $\begin{array}{l}0.4821 * * * \\
(0.0684)\end{array}$ & $\begin{array}{l}0.1611 * * * \\
(0.0438)\end{array}$ & $\begin{array}{l}0.1860 * * * \\
(0.0647)\end{array}$ & $\begin{array}{l}0.0920 * \\
(0.0468)\end{array}$ & $\begin{array}{l}0.0441 * \\
(0.0240)\end{array}$ & $\begin{array}{l}5.1995 * * * \\
(0.7214)\end{array}$ \\
\hline Constant & $\begin{array}{l}7.0772 * * * \\
(0.4594)\end{array}$ & $\begin{array}{l}9.9665 * * * \\
(0.2940)\end{array}$ & $\begin{array}{l}11.0943 * * * \\
(0.4342)\end{array}$ & $\begin{array}{l}2.4778 * * * \\
(0.3143)\end{array}$ & $\begin{array}{l}0.5391 * * * \\
(0.1613)\end{array}$ & $\begin{array}{l}37.5250 * * * \\
(4.8426)\end{array}$ \\
\hline$R^{2}$ & 0.6312 & 0.3180 & 0.2219 & 0.1176 & 0.1041 & 0.6417 \\
\hline Observations & 31 & 31 & 31 & 31 & 31 & 31 \\
\hline
\end{tabular}




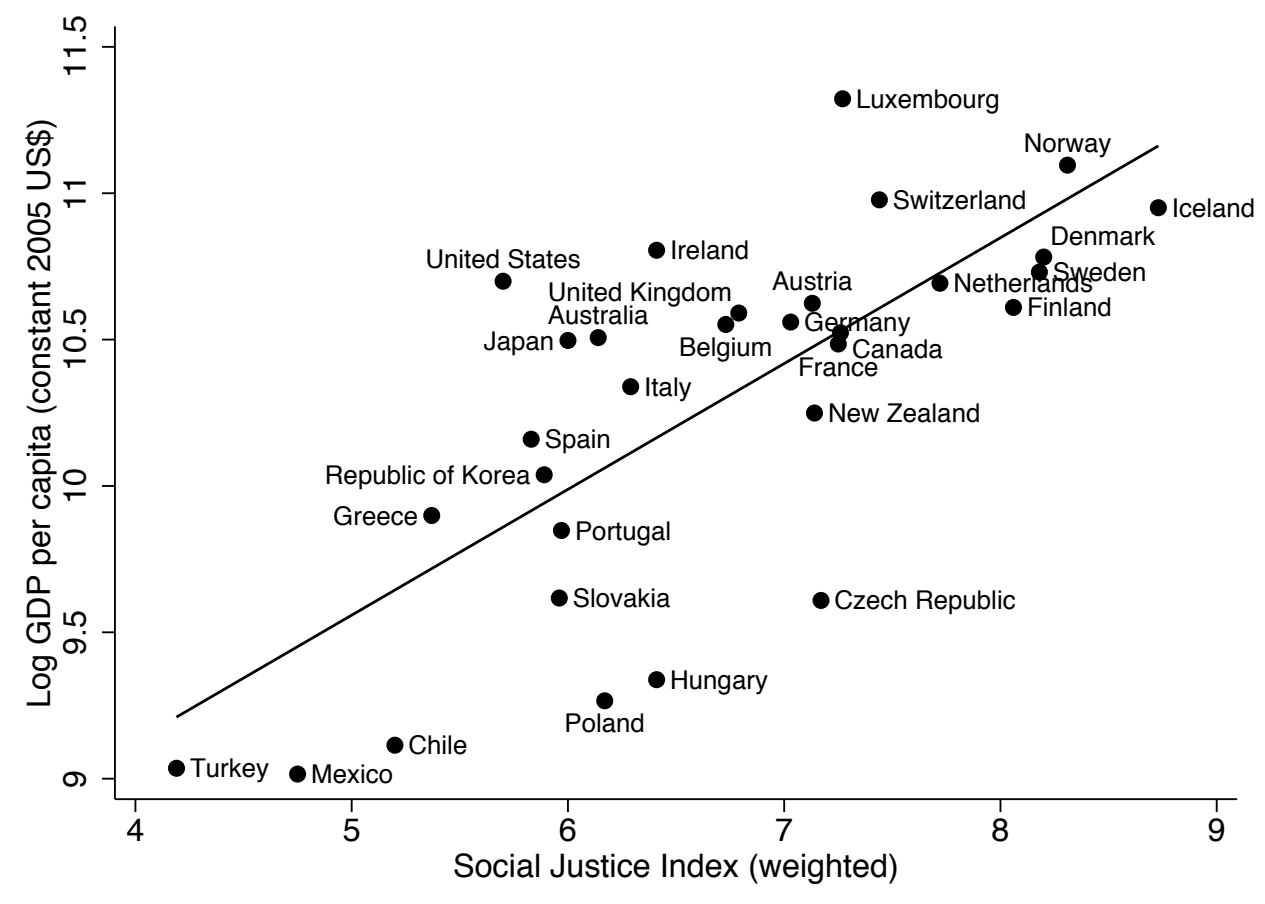

Figure 1: OCED: Log GDP per capita on Social Justice Index (2011) 


\subsubsection{IV: Two-stage least-squares}

The ordinary least squares describe the relationship between social justice and log GDP. Nonetheless, feedback from output per worker and log GDP back to social justice is possible. Obviously, wealthy countries would have more resources to promote social justice effectively. This paper follows Hall and Jones (1999) by adopting geographical characteristics of the economy as instrumental variables to control for this feedback. Hall and Jones (1999) highlight that geographical characteristic provides a measure of the influence from Western Europe. Equation (9) and (10) are adopted for the first and second stage respectively. In the first stage, the fitted values of social justice are obtained. This fitted values are then used to undertake regressions in the second stage.

$$
\begin{aligned}
S J_{k i} & =\alpha_{k}^{b}+\kappa_{k} I_{i}+\varepsilon_{k i}^{b} \\
Y_{j i} & =\alpha_{j k}^{c}+\mu_{j k} S J_{F_{k i}}+\varepsilon_{j k i}^{c}
\end{aligned}
$$

$I_{i}$ is latitude

$S J_{F_{k i}}$ are the fitted social justice values.

The results are provided in Table 3 and Table 4. After controlling for endogeneity differences in social justice accounts for a large amount of variations in economic performance. The $R^{2}$ as shown in column (1) of Table 3 and Table 4 are over $53 \%$ and $62 \%$. The coefficients on the weighted and unweighted social justice indices dropped slightly from 0.43 (Table 1) and 0.48 (Table 2) to 0.38 (Table 3 ) and 0.43 (Table 4) respectively. Nonetheless, both are still significant at a $1 \%$ level. The impact is still considerable. GDP per capita increases by $47 \%$ and $61 \%$ for only one point increase in the weighted and unweighted social justice indices. The results provided in column (2)-(6) of Table 3 and Table 4 are similar to the OLS regression (Table 1 and Table 2) in both coefficients and significance levels. In summary, the two-stage least squares confirm that after controlling for latitude, social justice still has a considerable impact on GDP per capita.

However, a limitation of this analysis is whether excluding the effect through social justice, latitude has an impact on economic performance. For instance, Sachs (2012) in his critique of Acemoglu and Robinson (2012) argues that geographic conditions in Sub-Saharan Africa are a major reason why the governments are weak. The author emphasises low population densities, disease, lack of navigable rivers, shortage of resources such as coal as barriers to strong central governments and growth. Consequently, in the next section, other controls will be introduced in order to ensure robustness of the analysis. 
Table 3: Instrumental Variables (2SLS) regressions: Weighted Social Justice Index

\begin{tabular}{|c|c|c|c|c|c|c|}
\hline & $\begin{array}{l}(1) \\
\text { Log GDP } \\
\text { /Capita }\end{array}$ & $\begin{array}{l}\text { (2) } \\
\text { Log Output } \\
\text { /Worker }\end{array}$ & $\begin{array}{l}\text { (3) } \\
\text { Log Physical Capital } \\
\text { /Worker }\end{array}$ & $\begin{array}{l}\text { (4) } \\
\text { Human Capital } \\
\text { /Worker }\end{array}$ & $\begin{array}{l}(5) \\
\text { Total Factor } \\
\text { Productivity }\end{array}$ & $\begin{array}{l}(6) \\
\text { Labour Participation } \\
\text { Rate }\end{array}$ \\
\hline Social Justice (Weighted) & $\begin{array}{l}0.3837 * * * \\
(0.0886)\end{array}$ & $\begin{array}{l}0.1589 * * * \\
(0.0527)\end{array}$ & $\begin{array}{l}0.1583 * * \\
(0.0753)\end{array}$ & $\begin{array}{l}0.0368 \\
(0.0553)\end{array}$ & $\begin{array}{l}0.0614 * * \\
(0.0287)\end{array}$ & $\begin{array}{l}3.5639 * * * \\
(0.9487)\end{array}$ \\
\hline Constant & $\begin{array}{l}7.717 * * * \\
(0.5961)\end{array}$ & $\begin{array}{l}9.9757 * * * \\
(0.3543)\end{array}$ & $\begin{array}{l}11.2723 * * * \\
(0.5066)\end{array}$ & $\begin{array}{l}2.8427 * * * \\
(0.3721)\end{array}$ & $\begin{array}{l}0.4227 * * \\
(0.1930)\end{array}$ & $\begin{array}{l}48.2511 \text { *** } \\
(6.3792)\end{array}$ \\
\hline$R^{2}$ & 0.5294 & 0.2492 & 0.1970 & 0.0625 & 0.0288 & 0.5288 \\
\hline Observations & 31 & 31 & 31 & 31 & 31 & 31 \\
\hline
\end{tabular}

Table 4: Instrumental Variables (2SLS) regressions: Unweighted Social Justice Index

\begin{tabular}{|c|c|c|c|c|c|c|}
\hline & $\begin{array}{l}\text { (1) } \\
\text { Log GDP } \\
\text { /Capita }\end{array}$ & $\begin{array}{l}\text { (2) } \\
\text { Log Output } \\
\text { /Worker }\end{array}$ & $\begin{array}{l}(3) \\
\text { Log Physical Capital } \\
\text { /Worker }\end{array}$ & $\begin{array}{l}\text { (4) } \\
\text { Human Capital } \\
\text { /Worker }\end{array}$ & $\begin{array}{l}(5) \\
\text { Total Factor } \\
\text { Productivity }\end{array}$ & $\begin{array}{l}(6) \\
\text { Labour Participation } \\
\text { Rate }\end{array}$ \\
\hline Social Justice (Unweighted) & $\begin{array}{l}0.4294 * * * \\
(0.0887)\end{array}$ & $\begin{array}{l}0.1778 * * * \\
(0.0563)\end{array}$ & $\begin{array}{l}0.1772 * * \\
(0.0830)\end{array}$ & $\begin{array}{l}0.0412 \\
(0.0613)\end{array}$ & $\begin{array}{l}0.0687 * * \\
(0.0314)\end{array}$ & $\begin{array}{l}3.9885^{* * * *} \\
(0.9697)\end{array}$ \\
\hline Constant & $\begin{array}{l}7.4271 * * * \\
(0.5926)\end{array}$ & $\begin{array}{l}9.8556 * * * \\
(0.3763)\end{array}$ & $\begin{array}{l}11.1527 * * * \\
(0.5545)\end{array}$ & $\begin{array}{l}2.8148 * * * \\
(0.4094)\end{array}$ & $\begin{array}{l}0.3763 * \\
(0.2097)\end{array}$ & $\begin{array}{l}45.5575 * * * \\
(6.4763)\end{array}$ \\
\hline$R^{2}$ & 0.6236 & 0.3146 & 0.2214 & 0.0817 & 0.0719 & 0.6069 \\
\hline Observations & 31 & 31 & 31 & 31 & 31 & 31 \\
\hline
\end{tabular}




\subsubsection{Two-stage least-squares \\ Robustness: controls}

The validity of the 2SLS results in Table 3 and 4 depend on the assumption that latitude has no direct impact on economic performance. Given that it was also used by Hall and Jones (1999) this presumption appears logical. Nonetheless, this paper substantiates the results further by controlling for variables that may be correlated with social justice and economic performance. Three types of controls are categorised, nature, social and other. The regressions take the form below. Equation (11) and (12) are the first and second stages respectively.

$$
\begin{array}{r}
S J_{k i}=\alpha_{k}^{d}+a_{k} I_{i}+\mathbf{X}_{\mathbf{m i}}^{\prime} \mathbf{d}_{\mathbf{k m}}+\varepsilon_{k m i}^{d} \\
Y_{j i}=\alpha_{j k m}^{e}+b_{j k m} S J_{F_{k i}}+\mathbf{X}_{\mathbf{m i}}^{\prime} \mathbf{c}_{\mathbf{j k m}}+\varepsilon_{j k m i}^{e}
\end{array}
$$

$j=1$ specifying $\log$ GDP per capita

$k=1$ specifying the weighted social justice index.

$m=\{1,2,3\}$

$\mathbf{X}_{\mathbf{m i}}$ is the vector of controls for each category (nature, social and other). The coefficients are also vectors. ${ }^{10}$

The results are provided in the appendix. Consider the impact of nature as a control. As can be seen, nature includes various temperature measures including average temperature, minimum monthly high etc., numerous humidity measures and a composite of various resources. The coefficient of latitude in the first stage of the regressions is all positive and significant at $1 \%$ level. This implies that latitude is a good instrument variable for social justice. The coefficients on the weighted social justice index are all significant and similar to first stage regression. When all controls for nature are added the coefficient is 0.555 .

\footnotetext{
${ }^{10}$ To simplify notation we represent the vector of controls by $\mathbf{X}_{\mathbf{m i}}$. However, in reality, we add the control in sets. For instance, for the nature control we add each set; temperature, humidity, and resources one by one. To see the various regressions consult the appendix.
} 


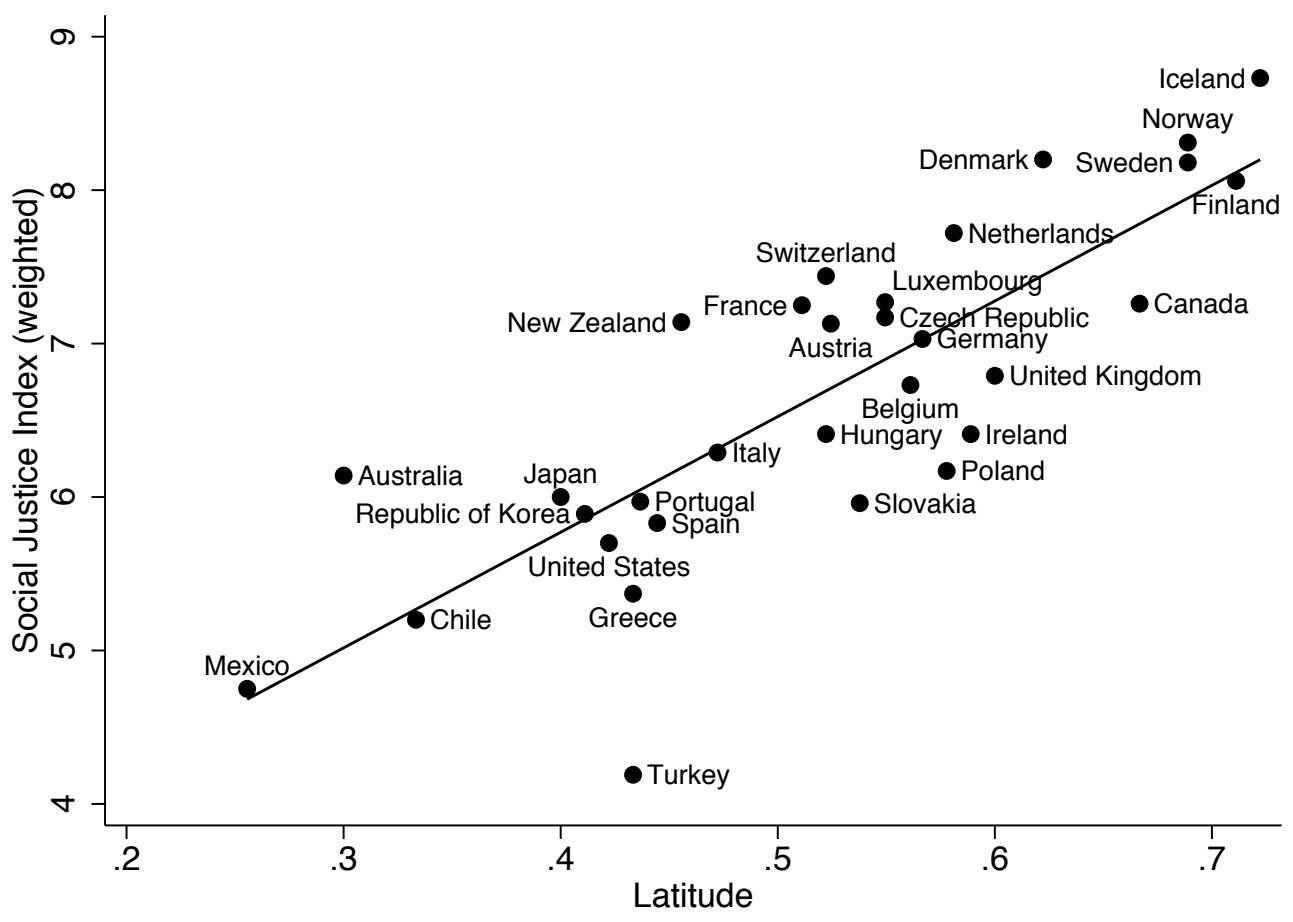

Figure 2: OECD:Social Justice on Latitude (2011) 
Social controls include legal origin. La Porta, Lopez-de-Silanes, Shleifer, and Vishny (1999) highlighted that the origination of the legal system is important. Consequently, a dummy variable for the legal system originating in France is included. The authors go on to argue that British colonies tend to have better institutions. Consequently, history is added with a dummy equating to 1 if the economy was governed by Great Britain. Religion is also considered important in economic performance. This paper adds Catholic, Islam and other religions. Acemoglu et al. (2001) adopted both legal and religion as controls. This paper also includes ethnic and ethnolinguistic concerns.

The third set of controls is other. These include urbanisation, economy size, country area, access to the sea. For instance, Rodrik et al. (2004) emphasised the importance of access to the sea, hence this is included.

\subsection{EU regressions}

This section provides the analysis for the EU countries utilising panel data with social justice indices for three years $(2008,2011,2014)$. Latitude as an instrumental variable is inappropriate as it does not change throughout the years. However, four different methods were applied to the data ensuring robustness, Pooled Ordinary Least Squares, Random Effects, Fixed Effects and Between Estimates. In addition, the data was treated in three different ways.

The first way used three years of panel data. GDP per capita for 2008, 2011, 2014 was used to undertake the regressions. The second way adopted eight years of panel data. The social justice index for 2008 was assigned for log GDP per capita for 2007, 2008 and 2009 years. The social justice index for 2011 was assigned for log GDP per capita for 2010, 2011 and 2012 years. The social justice index for 2014 was assigned for $\log$ GDP per capita for 2013 and 2014 years. The third way was to separate the years into three periods assigning a rating for each period. Period 1: 2007-2009, period 2: 2010-2012, period 3: 2013-2014. For each period the average log GDP per capita was adopted for the corresponding index for those periods, period 1: 2008, period 2: 2011, period 3: 2014.

Surprisingly, the results were nearly exactly the same for all the treatments. Specifically, the magnitude of the coefficients and all results were in similar ranges. The Nordic countries of Finland, Sweden, Denmark do particularly well in the social justice index and also has high GDP per capita. If Hungary was able to raise its rating to the Nordic countries that GDP per capita may increase from $14,892 \operatorname{USD}\left(e^{7.6515+0.4349(4.5)}\right)$ to 54,899 USD $\left(e^{7.6515+0.4349(7.5)}\right)$. However, the figure seems to suggest that improving social justice is not an easy task. Specifically, social justice for many of the EU countries has declined significantly. Note that this may have been due to global financial crisis during the period. From 2008 to 2014, Greece, Italy, and Ireland have decreased by over a point. ${ }^{11}$ In contrast, in countries at the top range, such as the

\footnotetext{
${ }^{11}$ Schraad-Tischler (2016) provides social justice indexes for 2015 and 2016. The social justice index for Greece is still worse in 2016 (4.37) than 2008 (6.01). The overall social justice average is 5.61 (2016) compared to 6.52 (2008). Note we did not use these social justice indexes as the corresponding GDP per capita was unavailable at the time of regressions. Nonetheless, the main results will not change with updated data.
} 
Nordic countries, the index has been relatively stable. The poor rating of the United Kingdom is quite thought-provoking. The reports compiled by Bertelsmann Stiftung (Schraad-Tischler, 2011) highlight that in the United Kingdom $32.6 \%$ of people under the age of 18 are at risk of poverty and social exclusion. Bulgaria and Romania fare poorly in social justice. Nonetheless, relative to their log GDP per capita, their social justice rating is fair. It is worth returning to a critical assumption of this work which is that economic performance does not affect social justice. Instrumental variable analysis and controls suggest that this assumption is justified. 


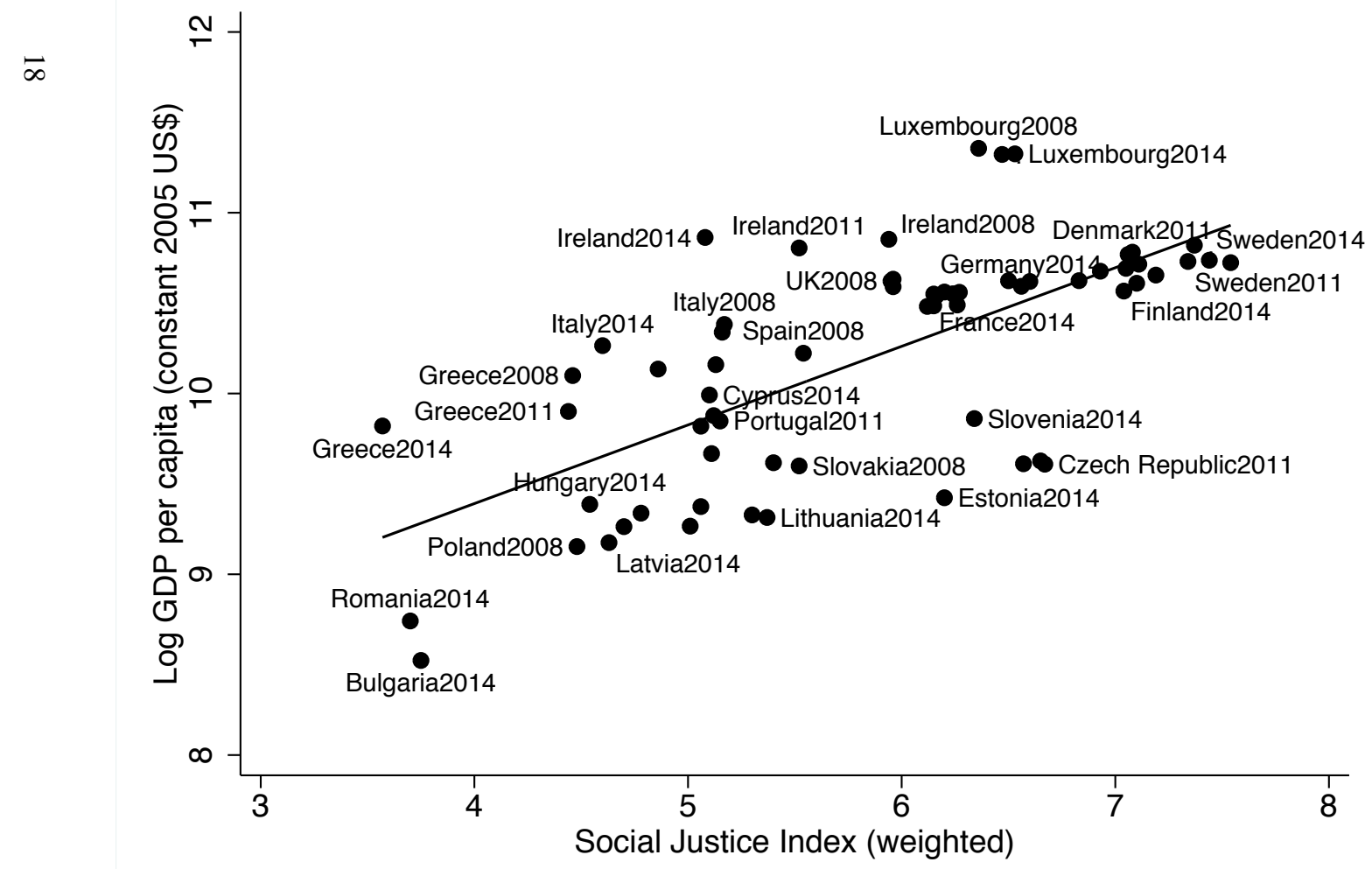


Table 5: Three Years of Panel: 2008, 2011, 2014

\begin{tabular}{|c|c|c|c|c|c|c|c|c|}
\hline & $\begin{array}{l}(1) \\
\text { Pooled } \\
\text { OLS }\end{array}$ & $\begin{array}{l}(2) \\
\text { Fixed } \\
\text { Effect }\end{array}$ & $\begin{array}{l}(3) \\
\text { Random } \\
\text { Effect }\end{array}$ & $\begin{array}{l}(4) \\
\text { Between } \\
\text { Effect }\end{array}$ & $\begin{array}{l}(5) \\
\text { Pooled } \\
\text { OLS }\end{array}$ & $\begin{array}{l}(6) \\
\text { Fixed } \\
\text { Effect }\end{array}$ & $\begin{array}{l}(7) \\
\text { Random } \\
\text { Effect }\end{array}$ & $\begin{array}{l}(8) \\
\text { Between } \\
\text { Estimates }\end{array}$ \\
\hline Social Justice (Weighted) & $\begin{array}{l}0.4349 * * * \\
(0.0591)\end{array}$ & $\begin{array}{l}0.1164 * * * \\
(0.0261)\end{array}$ & $\begin{array}{l}0.1450 * * * \\
(0.0280)\end{array}$ & $\begin{array}{l}0.5056 * * * \\
(0.0928)\end{array}$ & & & & \\
\hline Social Justice (Unweighted) & & & & & $\begin{array}{l}0.4574 * * * \\
(0.0612)\end{array}$ & $\begin{array}{l}0.1277 * * * \\
(0.0316)\end{array}$ & $\begin{array}{l}0.1637 * * * \\
(0.0333)\end{array}$ & $\begin{array}{l}0.5323 * * * \\
(0.1012)\end{array}$ \\
\hline Constant & $\begin{array}{l}7.6852 * * * \\
(0.3498)\end{array}$ & $\begin{array}{l}9.5096 * * * \\
(0.1524)\end{array}$ & $\begin{array}{l}9.1902 * * * \\
(0.1909)\end{array}$ & $\begin{array}{l}7.1467 * * * \\
(0.5340)\end{array}$ & $\begin{array}{l}7.4809 * * * \\
(0.3669)\end{array}$ & $\begin{array}{l}9.4329 * * * \\
(0.1872)\end{array}$ & $\begin{array}{l}9.0663 * * * \\
(0.2198)\end{array}$ & $\begin{array}{l}6.9365 * * * \\
(0.5921)\end{array}$ \\
\hline $\begin{array}{l}\text { Observations } \\
R^{2}\end{array}$ & $\begin{array}{l}65 \\
0.4621\end{array}$ & $\begin{array}{l}65 \\
0.3494\end{array}$ & 65 & $\begin{array}{l}65 \\
0.5430\end{array}$ & $\begin{array}{l}65 \\
0.4701\end{array}$ & $\begin{array}{l}65 \\
0.3060\end{array}$ & 65 & $\begin{array}{l}65 \\
0.5256\end{array}$ \\
\hline
\end{tabular}


Table 6: Eight Years of Panel Data: 2007-2014

\begin{tabular}{|c|c|c|c|c|c|c|c|c|}
\hline Variables & $\begin{array}{l}(1) \\
\text { Pooled } \\
\text { OLS }\end{array}$ & $\begin{array}{l}(2) \\
\text { Fixed } \\
\text { Effect }\end{array}$ & $\begin{array}{l}(3) \\
\text { Random } \\
\text { Effect }\end{array}$ & $\begin{array}{l}(4) \\
\text { Between } \\
\text { Effect }\end{array}$ & $\begin{array}{l}(5) \\
\text { Pooled } \\
\text { OLS }\end{array}$ & $\begin{array}{l}(6) \\
\text { Fixed } \\
\text { Effect }\end{array}$ & $\begin{array}{l}(7) \\
\text { Random } \\
\text { Effect }\end{array}$ & $\begin{array}{l}(8) \\
\text { Between } \\
\text { Estimates }\end{array}$ \\
\hline Social Justice (Weighted) & $\begin{array}{l}0.4291 * * * \\
(0.0367)\end{array}$ & $\begin{array}{l}0.1072 * * * \\
(0.0166)\end{array}$ & $\begin{array}{l}0.1202 * * * \\
(0.0172)\end{array}$ & $\begin{array}{l}0.5128 * * * \\
(0.0913)\end{array}$ & & & & \\
\hline Social Justice (Unweighted) & & & & & $\begin{array}{l}0.4498 * * * \\
(0.0376)\end{array}$ & $\begin{array}{l}0.1115 * * * \\
(0.0199)\end{array}$ & $\begin{array}{l}0.1280 * * * \\
(0.0205)\end{array}$ & $\begin{array}{l}0.5390 * * * \\
(0.0996)\end{array}$ \\
\hline Constant & $\begin{array}{l}7.6852 * * * \\
(0.2182)\end{array}$ & $\begin{array}{l}9.5750 * * * \\
(0.0974)\end{array}$ & $\begin{array}{l}9.3101 * * * \\
(0.1370)\end{array}$ & $\begin{array}{l}7.0847 * * * \\
(0.5257)\end{array}$ & $\begin{array}{l}7.5279 * * * \\
(0.2262)\end{array}$ & $\begin{array}{l}9.5409 * * * \\
(0.1187)\end{array}$ & $\begin{array}{l}9.2521 * * * \\
(0.1537)\end{array}$ & $\begin{array}{l}6.8790 * * * \\
(0.5823)\end{array}$ \\
\hline $\begin{array}{l}\text { Observations } \\
R^{2}\end{array}$ & $\begin{array}{l}169 \\
0.4506\end{array}$ & $\begin{array}{l}169 \\
0.2299\end{array}$ & 169 & $\begin{array}{l}169 \\
0.5479\end{array}$ & $\begin{array}{l}169 \\
0.4621\end{array}$ & $\begin{array}{l}169 \\
0.1826\end{array}$ & 169 & $\begin{array}{l}169 \\
0.5299\end{array}$ \\
\hline
\end{tabular}


Table 7: Three Periods: Average GDP/Capita

\begin{tabular}{|c|c|c|c|c|c|c|c|c|}
\hline & $\begin{array}{l}(1) \\
\text { Pooled } \\
\text { OLS }\end{array}$ & $\begin{array}{l}(2) \\
\text { Fixed } \\
\text { Effect }\end{array}$ & $\begin{array}{l}(3) \\
\text { Random } \\
\text { Effect }\end{array}$ & $\begin{array}{l}(4) \\
\text { Between } \\
\text { Effect }\end{array}$ & $\begin{array}{l}(5) \\
\text { Pooled } \\
\text { OLS }\end{array}$ & $\begin{array}{l}(6) \\
\text { Fixed } \\
\text { Effect }\end{array}$ & $\begin{array}{l}(7) \\
\text { Random } \\
\text { Effect }\end{array}$ & $\begin{array}{l}(8) \\
\text { Between } \\
\text { Estimates }\end{array}$ \\
\hline Social Justice (Weighted) & $\begin{array}{l}0.4359 * * * \\
(0.0591)\end{array}$ & $\begin{array}{l}0.1078 * * * \\
(0.0245)\end{array}$ & $\begin{array}{l}0.1344 * * * \\
(0.0266)\end{array}$ & $\begin{array}{l}0.5068 * * * \\
(0.0917)\end{array}$ & & & & \\
\hline Social Justice (Unweighted) & & & & & $\begin{array}{l}0.4585 * * * \\
(0.0611)\end{array}$ & $\begin{array}{l}0.1115^{* * * *} \\
(0.0300)\end{array}$ & $\begin{array}{l}0.1496 * * * \\
(0.0319)\end{array}$ & $\begin{array}{l}0.5331 * * * \\
(0.0997)\end{array}$ \\
\hline Constant & $\begin{array}{l}7.6311 * * * \\
(0.3491)\end{array}$ & $\begin{array}{l}9.5430 * * * \\
(0.1428)\end{array}$ & $\begin{array}{l}9.2309 * * * \\
(0.1825)\end{array}$ & $\begin{array}{l}7.1256 * * * \\
(0.5268)\end{array}$ & $\begin{array}{l}7.4603 * * * \\
(0.3557)\end{array}$ & $\begin{array}{l}9.4919 * * * \\
(0.1773)\end{array}$ & $\begin{array}{l}9.1288 * * * \\
(0.2116)\end{array}$ & $\begin{array}{l}6.9169 * * * \\
(0.5825)\end{array}$ \\
\hline $\begin{array}{l}\text { Observations } \\
R^{2}\end{array}$ & $\begin{array}{l}66 \\
0.4598\end{array}$ & $\begin{array}{l}66 \\
0.3439\end{array}$ & 66 & $\begin{array}{l}66 \\
0.5399\end{array}$ & $\begin{array}{l}66 \\
0.4684\end{array}$ & $\begin{array}{l}66 \\
0.2845\end{array}$ & 66 & $\begin{array}{l}66 \\
0.5237\end{array}$ \\
\hline
\end{tabular}




\section{Does Social Justice Contribute to Neoclassical Mod- els?}

This section determines whether social justice contributes to traditional economic neoclassical analysis. Due to data constraints, only the OECD countries are considered. Although, there may be multicollinearity problem, this analysis is really only a thought experiment. The year of analysis is 2011. To investigate the added benefit of introducing social justice, first, a traditional neoclassical model as outlined by Barro and Lee (1994) is adopted. Nonetheless, due to the problem of convergence and the catch-up effect, the focus here is on economic performance and output rather than growth as in Barro and Lee (1994). We start with the basic neoclassical model that relates output to the stock of human capital and stock of physical capital which is as follows. We include two measurements of labour.

$$
Y_{j i}=\alpha_{j k}^{f}+v_{j k} A_{i}+\gamma_{j k} K_{i}+v_{j k} L_{1 i}+\Lambda_{j k} L_{2 i}+\varepsilon_{j k i}^{f}
$$

$j=1$, hence $Y_{j i}$ is $\log$ GDP per capita .

$A_{i}$ is total factor productivity for country $i$

$K_{i}$ is $\log$ physical capital per worker for country $i$.

$L_{1 i}$ and $L_{2 i}$ is Labour participation rate and human capital per worker (we include two measurements of labour.)

The results of the basic neoclassical regression is shown in column (1) in Table 8. Social justice is then added to the basic neoclassical model as specified in equation (14) (column (2) and column (3)).

$$
Y_{j i}=\alpha_{j k}^{g}+r_{j k} A_{i}+p_{j k} K_{i}+o_{j k} L_{1 i}+u_{j k} L_{2 i}+h_{j k} S J_{k i}+\varepsilon_{j k i}^{g}
$$


Table 8: Contribution of Variables

\begin{tabular}{|c|c|c|c|c|}
\hline & $\begin{array}{l}\text { (1) } \\
\text { Log GDP } \\
\text { /Capita }\end{array}$ & $\begin{array}{l}\text { (2) } \\
\text { Log GDP } \\
\text { /Capita }\end{array}$ & $\begin{array}{l}\text { (3) } \\
\text { Log GDP } \\
\text { /Capita }\end{array}$ & $\begin{array}{l}\text { (4) } \\
\text { Log GDP } \\
\text { /Capita }\end{array}$ \\
\hline Log Physical Capital/Worker & $\begin{array}{l}0.7987 * * * \\
(0.1145)\end{array}$ & $\begin{array}{l}0.7323 * * * \\
(0.1101)\end{array}$ & $\begin{array}{l}0.7100 * * * \\
(0.1052)\end{array}$ & $\begin{array}{l}0.7878 * * * \\
(0.1168)\end{array}$ \\
\hline Human Capital/Worker & $\begin{array}{l}0.1529 \\
(0.1635)\end{array}$ & $\begin{array}{l}0.1465 \\
(0.1517)\end{array}$ & $\begin{array}{l}0.115 \\
(0.1444)\end{array}$ & $\begin{array}{l}0.1605 \\
(0.1655)\end{array}$ \\
\hline Total Factor Productivity & $\begin{array}{l}1.4029 * * * \\
(0.3165)\end{array}$ & $\begin{array}{l}1.3343 * * * \\
(0.2951)\end{array}$ & $\begin{array}{l}1.2298 * * * \\
(0.2846)\end{array}$ & $\begin{array}{l}1.3359 * * * \\
(0.3334)\end{array}$ \\
\hline Labour Force Participation Rate & $\begin{array}{l}0.0385 * * * \\
(0.0071)\end{array}$ & $\begin{array}{l}0.0244 * * \\
(0.009)\end{array}$ & $\begin{array}{l}0.0180 * \\
(0.0094)\end{array}$ & $\begin{array}{l}0.0364 * * * \\
(0.0078)\end{array}$ \\
\hline Social Justice (Weighted) & & $\begin{array}{l}0.1331 * * \\
(0.0582)\end{array}$ & & \\
\hline Social Justice (Unweighted) & & & $\begin{array}{l}0.1919 * * * \\
(0.0654)\end{array}$ & \\
\hline Latitude & & & & $\begin{array}{l}0.3129 \\
(0.4443)\end{array}$ \\
\hline Constant & $\begin{array}{l}-3.9798 * * * \\
(1.3094)\end{array}$ & $\begin{array}{l}-2.9567 * * \\
(1.2943)\end{array}$ & $\begin{array}{l}-2.4220^{*} \\
(1.2683)\end{array}$ & $\begin{array}{l}-3.8166 \\
(1.3425)\end{array}$ \\
\hline Observations & 31 & 31 & 31 & 31 \\
\hline$R^{2}$-squared & 0.8828 & 0.903 & 0.9128 & 0.8851 \\
\hline
\end{tabular}

As can be seen in the Table 8 both the weighted and unweighted social justice indexes are significant. Considering this investigation, social justice may be able to contribute to traditional neoclassical models. Furthermore, latitude is not significant as shown in column (4). This implies it is a viable instrumental variable for social justice.

\section{Concluding Remarks}

Many papers have argued that institutions are a fundamental cause of economic performance. The hypothesis presented in this paper is that social justice is also fundamental. The argument rests on the notion that social justice impacts technology, labour, capital which in turn impacts economic performance. This argument is supported empirically in the cross-sectional analysis of OECD countries. The results are robust under IV analysis and controls. Furthermore, the impact on the economic performance of EU countries is supported under various panel data methods. The simple OLS regressions illustrate that for OECD countries a 1 point increase in the weighted social justice index would increase GDP per capita $61 \%$ when controlling for the endogeneity. ${ }^{12}$

This paper has policy implications. The findings suggest that social justice should be a component of governmental policy. For instance, if Turkey could increase its

\footnotetext{
${ }^{12}$ The impact appears large. Nonetheless, the difference in the social justice index between the bottom (4 points) and top-ranked countries ( 9 points) is only 5 points. Consequently, the results are logical.
} 
ranking to Norway, then GDP per capita may increase from 10,000 to 56, 000 US Dollars. Secondly, the analysis may provide guidance on which areas to target. Specifically, policies should be focused on the lagging areas of social justice (i.e. poverty prevention, inclusive education system, labour market access, social cohesion, health and inter-generational justice) and the potential impact on the proximate causes. An example would be for southern European countries to focus on poverty amongst children. In Greece, Spain and Portugal, the risk of poverty amongst children is $35.8 \%$, $36.7 \%$ and $31.7 \%$ (Schraad-Tischler, 2015). However, change in social justice does not happen over night. Individuals should have equal opportunities to improve health. There should be access to medical care, healthy living standards with inclusive policy. There should be income distribution, prevention of social exclusion with the integration of migrants into society. Wage gaps should be reduced.

Our investigation suffers from limitations. The sample does not include any developing economies. Would these results hold with a bigger sample including developing countries? It is difficult to say. One could find numerous examples of countries in South America that may have high social justice but poor economic performances. Similarly, the tiger economies of East Asian countries may have excellent economic performances but poor social justice. Unfortunately, a social justice index has not been compiled for these countries. However, this is an area where further research would be of interest. 


\section{Appendix}

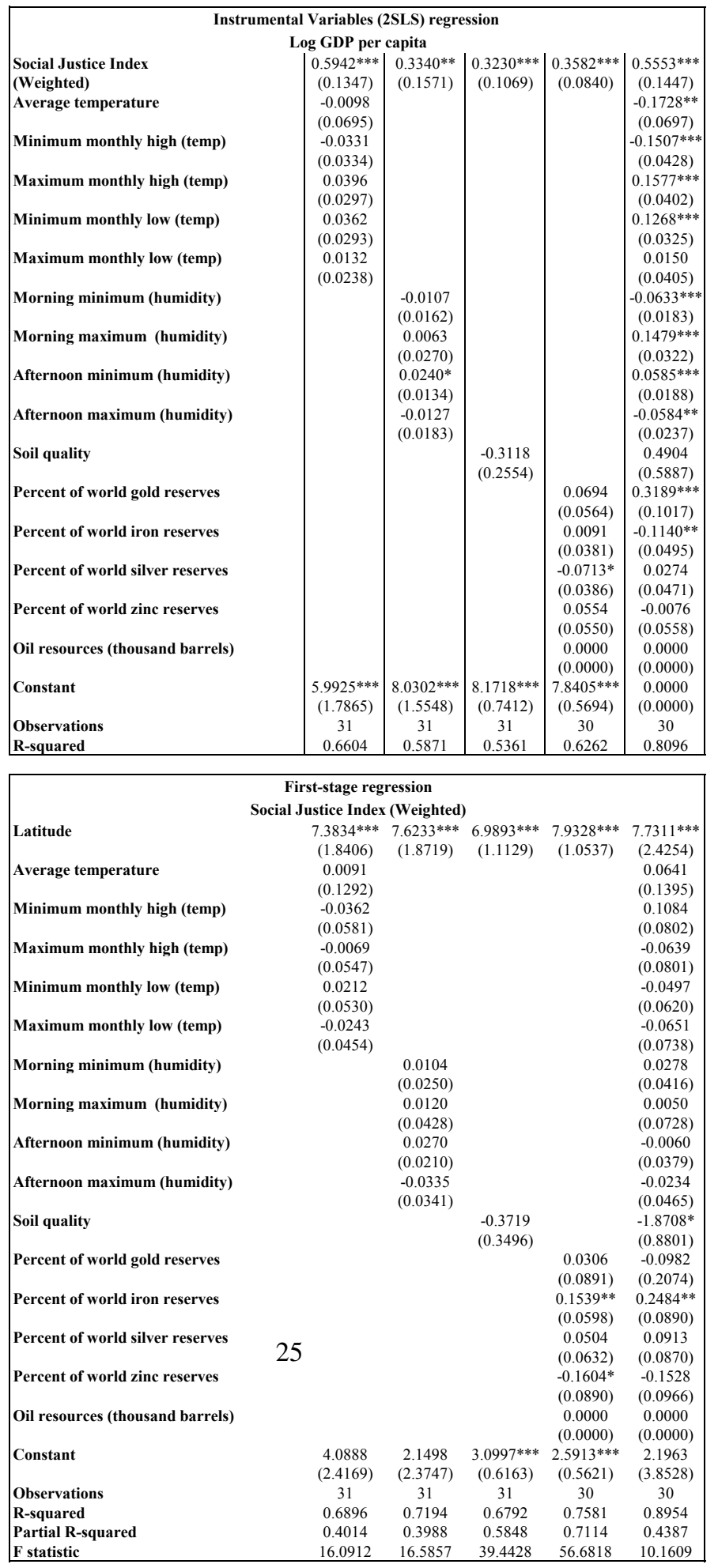




\begin{tabular}{|c|c|c|c|c|c|}
\hline \multicolumn{6}{|c|}{ Instrumental Variables (2SLS) regression } \\
\hline \multicolumn{6}{|c|}{ Log GDP per capita } \\
\hline Social Justice Index & $0.3580 * *$ & $0.4045^{* * *}$ & $0.3850 * * *$ & $0.3885^{* * *}$ & $0.4867 * * *$ \\
\hline (Weighted) & $(0.1710)$ & $(0.0829)$ & $(0.1029)$ & $(0.0802)$ & $(0.1579)$ \\
\hline Catholic & -0.0010 & & & & 0.0012 \\
\hline & $(0.0045)$ & & & & $(0.0041)$ \\
\hline Muslim & -0.0041 & & & & 0.0005 \\
\hline & $(0.0087)$ & & & & $(0.0078)$ \\
\hline Not Catholic/Muslim/Protestant & -0.0003 & & & & 0.0048 \\
\hline & $(0.0055)$ & & & & $(0.0050)$ \\
\hline British Colony & & $0.4019 * *$ & & & 0.3195 \\
\hline & & $(0.1964)$ & & & $(0.2224)$ \\
\hline Legal dummy 1 (France) & & & 0.0060 & & 0.0971 \\
\hline & & & $(0.1888)$ & & $(0.2022)$ \\
\hline Average ethnolinguistic fragmentation & & & & 1.0760 & 0.8969 \\
\hline & & & & $(0.7086)$ & $(0.7634)$ \\
\hline Constant & $7.9572 * * *$ & $7.5132 * * *$ & $7.7061 * * *$ & $7.5990 * * *$ & $6.6992 * * *$ \\
\hline & $(1.4629)$ & $(0.5603)$ & $(0.7274)$ & $(0.5479)$ & $(1.3386)$ \\
\hline Observations & 31 & 31 & 31 & 29 & 29 \\
\hline R-squared & 0.5332 & 0.5895 & 0.5298 & 0.6067 & 0.6795 \\
\hline
\end{tabular}

\begin{tabular}{|c|c|c|c|c|c|}
\hline \multicolumn{6}{|c|}{$\begin{array}{c}\text { First-stage regression } \\
\text { Social Justice Index (Weighted) }\end{array}$} \\
\hline Latitude & $\begin{array}{l}5.0863 * * * \\
(0.9461)\end{array}$ & $\begin{array}{c}7.5847 * * * \\
(1.0125)\end{array}$ & $\begin{array}{c}7.1028 * * * \\
(1.0850)\end{array}$ & $\begin{array}{c}7.5811^{* * * *} \\
(1.0081)\end{array}$ & $\begin{array}{c}5.0241 * * * \\
(1.0766)\end{array}$ \\
\hline Catholic & $\begin{array}{c}-0.0115^{* * *} \\
(0.0034)\end{array}$ & & & & $\begin{array}{c}-0.0121^{* * *} \\
(0.0040)\end{array}$ \\
\hline Muslim & $\begin{array}{c}-0.0297 * * * \\
(0.0057)\end{array}$ & & & & $\begin{array}{c}-0.0311 * * * \\
(0.0063)\end{array}$ \\
\hline Not Catholic/Muslim/Protestant & $\begin{array}{c}-0.0124 * * * \\
(0.0044)\end{array}$ & & & & $\begin{array}{c}-0.0135^{* * *} \\
(0.0047)\end{array}$ \\
\hline British Colony & & $\begin{array}{c}0.1288 \\
(0.3180)\end{array}$ & & & $\begin{array}{l}-0.0371 \\
(0.2991)\end{array}$ \\
\hline Legal dummy 1 (France) & & & $\begin{array}{l}-0.2559 \\
(0.2620)\end{array}$ & & $\begin{array}{c}0.0819 \\
(0.2794)\end{array}$ \\
\hline Average ethnolinguistic fragmentation & & & & $\begin{array}{l}-0.5620 \\
(1.1758)\end{array}$ & $\begin{array}{c}0.1554 \\
(1.0275)\end{array}$ \\
\hline Constant & $\begin{array}{c}4.9664 * * * \\
(0.6863)\end{array}$ & $\begin{array}{c}2.7099 * * * \\
(0.5467)\end{array}$ & $\begin{array}{c}3.0716 * * * \\
(0.6177)\end{array}$ & $\begin{array}{c}2.8199 * * * \\
(0.5462)\end{array}$ & $\begin{array}{c}5.0223 * * * \\
(0.7633)\end{array}$ \\
\hline Observations & 31 & 31 & 31 & 29 & 29 \\
\hline R-squared & 0.8403 & 0.6682 & 0.6772 & 0.6851 & 0.8610 \\
\hline Partial R-squared & 0.5264 & 0.6671 & 0.6048 & 0.6851 & 0.5091 \\
\hline F statistic & 28.9017 & 56.1157 & 42.8513 & 56.5585 & 21.7765 \\
\hline
\end{tabular}




\begin{tabular}{|c|c|c|c|c|c|c|}
\hline & & & & & & \\
\hline \multicolumn{7}{|c|}{ Instrumental Variables (2SLS) regression } \\
\hline Social Justice Index & $0.3690 * * *$ & $0.3782 * * *$ & $0.4526 * * *$ & $0.3690 * * *$ & $0.3879 * * *$ & $0.4095 * * *$ \\
\hline (Weighted) & $(0.0925)$ & $(0.0863)$ & $(0.0935)$ & $(0.0982)$ & $(0.0883)$ & $(0.0915)$ \\
\hline Trade (\% of GDP) & $\begin{array}{c}0.0008 \\
(0.0013)\end{array}$ & & & & & $\begin{array}{c}0.0018 \\
(0.0020)\end{array}$ \\
\hline Urban population (\%) & & $\begin{array}{c}0.0119 \\
(0.0077)\end{array}$ & & & & $\begin{array}{c}0.0072 \\
(0.0085)\end{array}$ \\
\hline Population & & & $\begin{array}{l}0.0026^{*} \\
(0.0014)\end{array}$ & & & $\begin{array}{c}0.0035 * * \\
(0.0015)\end{array}$ \\
\hline Log land area & & & & -0.0244 & & -0.0547 \\
\hline & & & & $(0.0508)$ & & $(0.0689)$ \\
\hline landlock & & & & & -0.1441 & -0.2055 \\
\hline & & & & & $(0.1950)$ & $(0.2475)$ \\
\hline Constant & $7.7404 * * *$ & $6.8244 * * *$ & $7.1528 * * *$ & $8.1029 * * *$ & $7.7169 * * *$ & $7.3290 * * *$ \\
\hline & $(0.5974)$ & $(0.6682)$ & $(0.6559)$ & $(1.0440)$ & $(0.5902)$ & $(1.1475)$ \\
\hline Observations & 31 & 31 & 31 & 29 & 31 & 29 \\
\hline R-squared & 0.5302 & 0.5664 & 0.5977 & 0.5239 & 0.5387 & 0.6447 \\
\hline
\end{tabular}

\begin{tabular}{|l|c|c|c|c|c|c|}
\hline & & \multicolumn{3}{|c|}{ First-stage regressions } \\
Latitude & $7.5117 * * *$ & $7.4332 * * *$ & $7.1400^{* * *}$ & $7.3115^{* * *}$ & $7.5028^{* * *}$ & $7.1488^{* * *}$ \\
& $(1.0491)$ & $(0.8807)$ & $(1.0716)$ & $(1.0566)$ & $(1.0057)$ & $(0.9600)$ \\
Urade (\% of GDP) & 0.0002 & & & & & -0.0044 \\
& $(0.0020)$ & & & & & $(0.0030)$ \\
Population & & $0.0289 * * *$ & & & & $0.0370 * * *$ \\
& & $(0.0098)$ & & & & $(0.0113)$ \\
Log land area & & & -0.0020 & & & -0.0021 \\
& & & $(0.0021)$ & & & $(0.0021)$ \\
landlock & & & & -0.0575 & & -0.0592 \\
& & & & $(0.0718)$ & & $(0.1005)$ \\
Constant & & & & & 0.1426 & $0.7791 * *$ \\
& & & & & $(0.2941)$ & $(0.3606)$ \\
Observations & $2.7534 * * *$ & 0.5399 & $3.0411 * * *$ & $3.5590 * * *$ & $2.7456 * * *$ & 1.0918 \\
R-squared & $(0.5377)$ & $(0.8847)$ & $(0.6032)$ & $(1.1260)$ & $(0.5341)$ & $(1.6312)$ \\
Partial R-squared & 31 & 31 & 31 & 29 & 31 & 29 \\
F statistic & 0.6663 & 0.7455 & 0.6771 & 0.6893 & 0.6690 & 0.8050 \\
& 0.6468 & 0.7178 & 0.6132 & 0.6654 & 0.6653 & 0.7160 \\
\hline
\end{tabular}




\section{References}

Acemoglu, D., Johnson, S., \& Robinson, J. A. (2001). The colonial origins of comparative development: an empirical investigation: comment. The American Economic Review, 91(5), 1369-1401.

Acemoglu, D., Johnson, S., \& Robinson, J. A. (2002). Reversal of fortune: geography and institutions in the making of the modern world income distribution. Quarterly Journal of Economics, 117(4), 1231-1294.

Acemoglu, D., Johnson, S., \& Robinson, J. A. (2005). Institutions as a fundamental cause of long-run growth. Handbook of economic growth, 1, 385-472.

Acemoglu, D. \& Robinson, J. (2012). Why nations fail: the origins of power, prosperity, and poverty. Crown Business.

Aghion, P., Banerjee, A., \& Piketty, T. (1999). Dualism and macroeconomic volatility. Quarterly journal of economics, 1359-1397.

Albouy, D. (2004). The colonial origins of comparative development: a reexamination based on improved settler mortality data. Department of Economics, University of California-Berkeley, Working Paper.

Albouy, D. (2008). The colonial origins of comparative development: an investigation of the settler mortality data. National Bureau of Economic Research.

Albouy, D. (2012). The colonial origins of comparative development: an empirical investigation: comment. The American Economic Review, 102(6), 3059-3076.

Alesina, A. \& Perotti, R. (1996). Income distribution, political instability, and investment. European economic review, 40(6), 1203-1228.

Alesina, A. \& Rodrik, D. (1991). Distributive politics and economic growth. National bureau of economic research.

Banerjee, A. V. \& Newman, A. F. (1993). Occupational choice and the process of development. Journal of political economy, 274-298.

Barro, R. \& Lee, J. (1994). Sources of economic growth. Carnegie-Rochester Conference Series on Public Policy.

Benhabib, J. \& Spiegel, M. M. (1994). The role of human capital in economic development evidence from aggregate cross-country data. Journal of Monetary economics, 34(2), 143-173.

Bertelsmann Stiftung. (n.d.). Social justice index. [Online; accessed 1-March-2016]. Retrieved 2016, from http://www.sgi-network.org/sgi-studies/

Carlin, W., Schaffer, M. E., \& Seabright, P. (2010). A framework for cross-country comparisons of public infrastructure constraints on firm growth.

Doepke, M. \& Zilibotti, F. (2014). Chapter 1 - culture, entrepreneurship, and growth. In P. Aghion \& S. N. Durlauf (Eds.), Handbook of economic growth (Vol. 2, pp. 148). Handbook of Economic Growth. Elsevier. doi:http://dx.doi.org/10.1016/ B978-0-444-53538-2.00001-0

Galor, O. (2000). Income distribution and the process of development. European Economic Review, 44(4), 706-712.

Galor, O. et al. (2009a). Inequality and economic development: an overview. Inequality and Economic Development: The Modern Perspective. Elgar Publishing. 
Galor, O., Moav, O., \& Vollrath, D. (2009b). Inequality in landownership, the emergence of human-capital promoting institutions, and the great divergence. The Review of economic studies, 76(1), 143-179.

Galor, O. \& Zang, H. (1997). Fertility, income distribution, and economic growth: theory and cross-country evidence. Japan and the world economy, 9(2), 197-229.

Galor, O. \& Zeira, J. (1993). Income distribution and macroeconomics. The review of economic studies, 60(1), 35-52.

Glaeser, E. L., La Porta, R., Lopez-de-Silanes, F., \& Shleifer, A. (2004). Do institutions cause growth? Journal of economic Growth, 9(3), 271-303.

Hall, R. E. \& Jones, C. I. (1999). Why do some countries produce so much more output per worker than others? Quarterly Journal of Economics, 114(1), 83-116.

La Porta, R., Lopez-de-Silanes, F., Shleifer, A., \& Vishny, R. (1999). The quality of government. Journal of Law, Economics, and organization, 15(1), 222-279.

Lee, J.-W. (2016a). China's economic growth and convergence.

Lee, J.-W. (2016b). The republic of korea's economic growth and catch-up: implications for the people's republic of china.

Miller, D. (1999). Principles of social justice. harvard university Press.

North, D. C. \& Thomas, R. P. (1973). The rise of the western world: a new economic history. Cambridge University Press.

Parker, S. C. (2009). The economics of entrepreneurship. Cambridge University Press.

Persson, T. \& Tabellini, G. (1994). Is inequality harmful for growth? The American Economic Review, 600-621.

Rawls, J. (2009). A theory of justice. Harvard university press.

Rodrik, D., Subramanian, A., \& Trebbi, F. (2004). Institutions rule: the primacy of institutions over geography and integration in economic development. Journal of economic growth, 9(2), 131-165.

Sachs, J. D. (2012). Government, geography, and growth: the true drivers of economic development. Foreign Affairs, 142-150.

Schraad-Tischler, D. (2011). Social justice in the oecd, how do the member states compare? Berlelsmann Stiftung.

Schraad-Tischler, D. (2015). Social justice in eu-index report 2015. Berlelsmann Stiftung.

Schraad-Tischler, D. (2016). Social justice in eu-index report 2016. Berlelsmann Stiftung.

Smith, A. (1776). An inquiry into the nature and causes ofthe wealth ofnations. London: George Routledge and Sons.

Temple, J. (1999). A positive effect of human capital on growth. Economics Letters, 65(1), 131-134.

University of Californa and the Groningen Growth Development Centre. (n.d.). Penn world table, version 8.1. [Online; accessed 1-March-2016]. Retrieved 2016, from http://www.rug.nl/ggdc/productivity/pwt/

Veblen, T. (1899). The theory of the leisure class: an economic study in the evolution of institutions.

Weil, D. N. (2014). Chapter 3 - health and economic growth. In P. Aghion \& S. N. Durlauf (Eds.), Handbook of economic growth (Vol. 2, pp. 623-682). Handbook of Economic Growth. Elsevier. doi:http://dx. doi.org/10.1016/B978- 0-44453540-5.00003-3 
Well, D. N. (2007). Accounting for the effect of health on economic growth. The Quarterly Journal of Economics, 122(3), 1265-1306. Retrieved from http:// EconPapers.repec.org/RePEc:oup:qjecon:v:122:y:2007:i:3:p:1265-1306.

Williamson, O. E. (1985). The economic intstitutions of capitalism. Simon and Schuster.

World Bank. (n.d.-a). Wdi database archives. [Online; accessed 1-March-2016]. Retrieved 2016, from http://databank. worldbank.org/data/reports. aspx ? source= wdi-database-archives-(beta)

World Bank. (n.d.-b). World bank open data. [Online; accessed 1-March-2016]. Retrieved 2016, from http://data.worldbank.org 